\title{
Economic Impact of Milk Production in the State of New Mexico ${ }^{1}$
}

\author{
V. E. Cabrera, ${ }^{\star 2,3}$ R. Hagevoort, ${ }^{\star}$ D. Solís,† R. Kirksey,‡ and J. A. Diemer§ \\ *Department of Extension Animal Sciences and Natural Resources, New Mexico State University, Clovis 88101 \\ †Division of Marine Affairs and Policy, Rosenstiel School of Marine and Atmospheric Science, \\ University of Miami, Coral Gables, FL 33149 \\ $\ddagger$ Department of Agricultural Economics and Agricultural Business, New Mexico State University, Clovis 88101 \\ $\S$ Department of Agricultural Economics and Agricultural Business, New Mexico State University, Las Cruces 88003
}

\section{ABSTRACT}

The goal of this study was to quantify the economic role of dairy farming in New Mexico and to identify its linkages with allied industries in terms of income, value added, and employment impacts. An input-output model was used to estimate the direct, indirect, and induced impacts of the dairy farm industry on the economy of New Mexico. The results showed that in 2005, New Mexico's dairy farm industry had a total economic impact of $\$ 1.98$ billion and accounted for 14,313 jobs. Therefore, dairy farming in New Mexico had an output multiplier (income) of 1.92, a labor income multiplier of $\$ 248$ thousand/\$ million of gross sales, and an employment multiplier of 13.91 jobs $/ \$$ million of gross sales. Furthermore, the New Mexico dairy farms accounted for $13.1 \%$ of the total agricultural outputs, $20.5 \%$ of the agricultural jobs, $1.5 \%$ of total state economic activity, and $\$ 80$ million in tax revenue. With the exception of Lea, Eddy, and Bernalillo counties, which are diversified, the dairy farms accounted for more than two-thirds of the agricultural outputs and for more than two-fifths of the agricultural employment in counties where dairy farms are concentrated.

Key words: impact analysis for planning model, regional economic analysis, input-output analysis, economic impact

\section{INTRODUCTION}

The US dairy sector has experienced significant structural changes in recent years. Following the global tendency for intensification, US dairy farms have decreased in number while increasing herd size and productivity

\footnotetext{
Received October 18, 2007.

Accepted January 15, 2008.

${ }^{1}$ This study was supported by the New Mexico Cooperative Extension Service, the New Mexico Agricultural Experiment Station, and a grant from DairyMax (Grand Prairie, TX; www.dairymax.org).

${ }^{2}$ Corresponding author: vcabrera@wisc.edu

${ }^{3}$ Current address: Dept. Dairy Science, University of WisconsinMadison, Madison 53706.
}

(Alvarez et al., 2007; USDA, 2007a). These changes are also linked to a geographical shift in dairy production. The western and southwestern dairy states (i.e., California, Nevada, Arizona, New Mexico, Texas, Colorado, Utah, Wyoming, Idaho) have rapidly increased their share of US milk production and now account for more than one-third of the US milk supply (Barham et al., 2005; USDA, 2007a).

As the role of the dairy farms increases in more recently prominent milk-producing states, quantifying the economic contribution of this industry to those states becomes necessary. This quantification is important for different reasons. Policy makers may use this information to identify the contributions of dairy farms to the economy (Helmberger and Chen, 1994), its potential repercussions for linked industries, and the overall benefits to the society (Balagtas et al., 2003). Knowing the economic impact of the dairy farms on the state economy is also important for dairy farmers. It provides them with a sense of pride in their economic contributions and an awareness of their responsibility to society. Additionally, public awareness of the economic contribution of the dairy farm industry contributes positively to the society's image of the industry.

One of the most significant changes in US dairy farming has occurred in the state of New Mexico. After decades of limited dairy activity, New Mexico now ranks seventh in the nation in milk production (with $4 \%$ of the total national milk production), fourth in productivity $(10,065 \mathrm{~kg} / \mathrm{cow}$ per year), and first in herd size $(2,080$ cows/farm; Cabrera and Hagevoort, 2007). The state's position is a result of rapid growth during the last 2 decades. In 2001, dairy farming became the most important agricultural industry in the state when it began generating more cash receipts than any other agricultural activity. In 2005, 3,175,000 Mg of milk produced and more than 100,000 dairy cows slaughtered for meat accounted for more than $40 \%$ of New Mexico's $\$ 2.6$ billion agricultural cash receipts (Cabrera and Hagevoort, 2007). As reported in Table 1, the eastern New Mexico dairy production area, including Chaves, Roosevelt, Curry, Lea, and Eddy counties, now accounts for more 
Table 1. Dairy farms and milk production in New Mexico, 1994 and 2005

\begin{tabular}{lccccccc}
\hline & \multicolumn{3}{c}{1994} & & \multicolumn{3}{c}{2005} \\
\cline { 2 - 3 } County & $\begin{array}{c}\text { Producers } \\
(\mathrm{n})\end{array}$ & $\begin{array}{c}\text { Milk } \\
\text { cows (n) }\end{array}$ & $\begin{array}{c}\text { Milk } \\
\text { production }^{1}(\%)\end{array}$ & $\begin{array}{c}\text { Producers } \\
(\mathrm{n})\end{array}$ & $\begin{array}{c}\text { Milk } \\
\text { cows (n) }\end{array}$ & $\begin{array}{c}\text { Milk } \\
\text { production }^{2}(\%)\end{array}$ \\
\hline Chaves & 40 & 56,500 & 37.5 & & 43 & 90,000 & 27.13 \\
Roosevelt & 30 & 18,000 & 12.3 & & 43 & 65,000 & 18.69 \\
Curry & 8 & 10,000 & 7.0 & & 26 & 66,000 & 18.29 \\
Dona Ana & 25 & 31,000 & 20.6 & & 26 & 53,000 & 15.75 \\
Eddy & 5 & 9,100 & 5.1 & & 6 & 19,000 & 4.21 \\
Valencia & 15 & 5,200 & 3.9 & & 9 & 4,000 & 2.68 \\
Socorro & 10 & 4,000 & 1.9 & & 8 & 11,000 & 2.24 \\
Bernalillo & 9 & 5,100 & 3.8 & & 4 & 2,000 & 0.89 \\
Other & 10 & 3,900 & 3.0 & & 8 & 5,000 & 3.18 \\
New Mexico & 150 & 150,000 & 100 & & 187 & 340,000 & 100 \\
\hline
\end{tabular}

${ }^{1}$ Total milk production in 1994 equals $1,503,570 \mathrm{Mg}$ of milk.

${ }^{2}$ Total milk production in 2005 equals $3,159,545 \mathrm{Mg}$ of milk.

${ }^{3}$ Four counties in 1994 (Sandoval, Sierra, San Juan, and Quay) and 3 in 2005 (Luna, Sierra, and Torrance) with less than 4 producers.

than $75 \%$ of the milk production in New Mexico (USDA, 2006).

The New Mexico milk processing infrastructure includes 14 dairy processing plants: 4 primarily devoted to cheese production, 4 fluid milk plants, 4 powder plants, 1 ice cream plant, and $1 \mathrm{UF}$ plant. Much of the product from these processing plants is marketed out of state. In 2005, New Mexico exported 23,600 Mg of NDM, 22,700 $\mathrm{Mg}$ of cheese, $13,400 \mathrm{Mg}$ of raw milk, 7,000 Mg of lactose, $3,400 \mathrm{Mg}$ of whey protein concentrate, and $400 \mathrm{Mg}$ of cream (A. Reef, New Mexico Department of Agriculture Dairy Bureau, Albuquerque, NM, personal communication). These exports are equivalent to $49,700 \mathrm{Mg}$ of milk solids: $47 \%$ as NDM, $28 \%$ as cheese, $3.5 \%$ as raw milk, $14 \%$ as lactose, $7 \%$ as whey, and $0.5 \%$ as cream.

Although dairy farming in New Mexico has shown a steady increase in production during the last 2 decades, questions remain about the future role of this industry in the state. In consequence, the purpose of this study was to quantify the economic role of dairy farming in New Mexico and identify the linkages between New Mexico's dairy farms and allied industries in terms of income, value added, and employment impacts. This study also provides empirical measures of the direct, indirect, and induced economic impacts as well as the labor income of the dairy farm industry in New Mexico. This study contributes to the limited body of literature on statespecific dairy farming economic impacts.

\section{MATERIALS AND METHODS}

This study uses an input-output (I/O) analysis to measure the contribution of the dairy farms to the economy of New Mexico. This method was derived from the general equilibrium model conceptualized by Leontief (1953). The I/O analysis uses an economic framework that traces the flow of goods and services, income, and employment among related sectors in a defined regional economy. Thus, its results can be interpreted as a snapshot of a regional economy in equilibrium. This methodology provides a means of examining relationships within an economy among different sectors, and between sectors and final consumers such as households and government. Consequently, the I/O model allows examination of the impact of a change in one or several economic activities on the entire economy on a regional basis (Minnesota IMPLAN Group, 2006).

Specifically, the I/O model uses linear relationships to reflect production processes that equate industry inputs and outputs (e.g., dairy farms) within a specific geographic region (e.g., New Mexico). Operationally, the I/O models are "demand driven" models, in which the demand for the output of an industry can be examined to determine its impacts on the other sectors of the economy as a result of their interdependences. These interdependences can be specified in levels of outputs (e.g., an increase in demand of $\$ 10$ million worth of fluid milk results in an increase of $\$ 1$ million demand for locally produced alfalfa hay). A detailed review on the I/O method can be found in Miller and Blair (1985) and Mon and Holland (2005).

The impacts of industry interdependences are often generalized in the form of multipliers (Boggess et al., 1997; Tavernier and Brumfield, 2003). The most common are type I (direct + indirect effects) and type II, or social accounting matrix $(\mathbf{S A M}=$ direct + indirect + induced effects). Direct impacts are essentially those resulting from dairy farm producers' purchases from their suppliers. Indirect impacts are those generated when dairy farm suppliers purchase inputs from their own suppliers. Induced impacts (typically thought of as longer term) result when income generated by successive rounds of 
interindustry transactions result in purchases of both consumable and durable goods (final demand) from the wages and salaries of those used in the economy being examined. Grocery purchases from dairy farm workers are induced economic impacts from the dairy farm industry.

For example, if a $\$ 10$ million increase in demand for fluid milk results in an increase of $\$ 6$ million in demand for other locally produced inputs in addition to a $\$ 1$ million increase in demand for alfalfa hay, the total direct + indirect impact of increased milk production on the local economy is $\$ 17$ million. Consequently, an additional $\$ 1.00$ in fluid milk demand results in a type I multiplier of 1.70. Dairy farming has great impacts on other agricultural industries that produce the goods and services required by the dairy farm industry (e.g., feed production, raising livestock operations, etc.).

Multipliers can be calculated to determine the impact of final demand changes on employment (including parttime and full-time workers, calculated as a function of the outputs in the context of the local economy), income (employee compensation, income of proprietors), value added (including employee compensation, income of proprietors, other property-type income, and direct business taxes), and output (total value of goods produced).

The I/O analysis has been used extensively to study the contribution of various sectors to the overall economy. In agriculture, it has been used to evaluate the economic impact of organic apple production in Washington (Mon and Holland, 2005); to evaluate the greenhouse, nursery, and sod industry within the United States (Tavernier and Brumfield, 2003); and to examine the whole agricultural industry in Oregon (Waters et al., 1999). This methodology has also been implemented to study the forest industry (Templeton and Goldman, 1996), tourism (Borden et al., 1996), and rural development (Robinson, 1997).

Relatively few published studies have used I/O analysis to estimate the economic impact of the dairy farm industry on regional economies. These include Hemmer (1998) for Maricopa County, Arizona; Seidl and Weiler (2000) for 5 northeastern Colorado counties; Ricketts (2000) for the state of Missouri; and Doherty and Morse (1999) for the state of Minnesota. This paper adds to this literature by offering a comprehensive empirical evaluation of the economic impacts of the dairy farm industry to the New Mexico economy at the state and county levels.

To implement our I/O analysis, we used the impact analysis for planning (IMPLAN) model. This model is based on the US national income, product accounts, and various other regional data sources. These data are regionalized to the county level to allow analyses to be performed at various levels of aggregation as warranted by the issue being studied (Rickman and Schwer, 1995; Minnesota IMPLAN Group, 2006). The IMPLAN model provides a rigorous framework for collecting, categorizing, and analyzing interindustry structure and interdependencies (Aruna et al., 1997).

Dairy farming affects the economy in New Mexico in 3 distinctive ways: 1 ) as a direct impact when processing plants buy milk or meat animals directly from the dairy farmers; 2) as an indirect impact by dairy farmers' hiring labor and purchasing feed, energy, livestock, real estate, and so on from allied industries to produce a final product (milk or meat); and 3) as an induced impact by the consumption effect of people used on dairy farms as well as allied industries. These contributions are analyzed in terms of industry outputs (sales value or direct impacts), employment (full- and part-time employees), labor income (ratio of output paid as labor expenditure), and added value to the economy (employee compensation, proprietary income, other types of income and indirect business taxes). The IMPLAN model also reports the taxes paid to the state by the studied industry. In this study, we also report New Mexico's tax revenue related to dairy farming economic activity.

Because IMPLAN is a backward economic linkage model, it includes only the impacts of the industry being studied. Consequently, economic impacts of the dairy processing industries are not within the scope of this study. The analysis presented here is limited to the impact of dairy farms (fluid milk and meat) on the New Mexico economy. New Mexico has a substantial dairy processing industry, and the economic impacts of the dairy processing activities are addressed in an upcoming companion study. Employment generated by individual dairy and meat processing activities is reported here as a matter of general interest.

The I/O analysis was performed by using the IMPLAN database (released in October 2006) and IMPLAN software (Minnesota IMPLAN Group, 2006). Structural matrices from the IMPLAN software were updated to December 2007. Dairy farm production data were obtained from the 2005 New Mexico Agricultural Statistics Bulletin (USDA, 2006). The analysis was conducted for the year 2005, with IMPLAN data adjusted by using the US Consumer Price Index. Supplemental employment data for dairy farm production in 2005 was obtained from the New Mexico Department of Labor (New Mexico Department of Labor Form 202, Albuquerque, NM, personal communication).

\section{RESULTS AND DISCUSSION}

\section{Direct Economic Impacts}

Our analyses showed that in 2005, dairy farm production contributed $\$ 1.03$ billion directly and the equivalent 
of 4,221 full-time equivalent (FTE) jobs to the economy of New Mexico (Table 2). Approximately, 4.10 jobs were created directly and sustained by every $\$ 1$ million in dairy farm product sales $(4,221$ jobs $/ \$ 1.03$ billion $)$. As a matter of interest, milk and meat processing activities also created jobs. These processing activities accounted for approximately 1.5 FTE for every $\$ 1$ million of sales of dairy farm products (1,661 jobs $/ \$ 1.03$ billion).

\section{Indirect Economic Impacts}

In 2005 , the dairy farm industry indirectly contributed $\$ 338$ million and 3,634 FTE to the New Mexico economy (Table 2). These indirect economic impacts promoted an additional value added of $\$ 177$ million to the New Mexico economy. As shown in Table 2, the dairy farm industry in New Mexico has important impacts in linked indus-

Table 2. Direct, indirect, and induced economic impacts of the New Mexico dairy industry, 2005

\begin{tabular}{|c|c|c|c|c|}
\hline \multirow[b]{2}{*}{$\mathrm{NAICS}^{1}$} & \multicolumn{4}{|c|}{ Direct economic impact } \\
\hline & Dairy farm production & & $\begin{array}{c}\text { Value } \\
(\$ 000,000)\end{array}$ & $\begin{array}{l}\text { Employment } \\
(\mathrm{FTE})^{2}\end{array}$ \\
\hline & Total production & & 1,029 & $4,221^{3}$ \\
\hline & Milk to processing sectors & & $980^{4}$ & $1,539^{3}$ \\
\hline 62 & Fluid milk manufacturing & & 389 & 718 \\
\hline 66 & Ice cream manufacturing & & 131 & 182 \\
\hline 64 & Cheese manufacturing & & 196 & 272 \\
\hline 63 & Creamery butter manufacturing & & 264 & 367 \\
\hline 68 & Meat animals & & $49^{4}$ & $122^{3}$ \\
\hline & Total direct impacts & & 1,029 & 4,221 \\
\hline & \multicolumn{4}{|c|}{ Indirect economic impact ${ }^{5}$} \\
\hline NAICS & Selected industry & $\begin{array}{c}\text { Indirect output } \\
(\$ 000,000)\end{array}$ & $\begin{array}{c}\text { Value added } \\
(\$ 000,000)\end{array}$ & Employment (FTE) \\
\hline 10 & All other crop farming & 10.0 & 2.3 & 48.3 \\
\hline 11 & Cattle and ranching farming & 16.9 & 2.8 & 132.2 \\
\hline 18 & Agriculture and forestry activities & 40.6 & 23.2 & $1,421.2$ \\
\hline 19 & Oil and gas extraction & 41.0 & 23.0 & 116.2 \\
\hline 30 & Power generation and supply & 8.6 & 5.9 & 19.1 \\
\hline $62-66$ & Milk processing & 0.0 & 0.0 & - \\
\hline 142 & Petroleum refineries & 54.3 & 2.5 & 13.8 \\
\hline 390 & Wholesale trade & 23.6 & 16.2 & 206.1 \\
\hline 394 & Truck transportation & 6.5 & 2.9 & 57.7 \\
\hline 431 & Real estate & 66.6 & 46.6 & 648.4 \\
\hline 450 & All other miscellaneous professional & 1.4 & 0.6 & 2.9 \\
\hline \multirow[b]{5}{*}{ NAICS } & Management of companies, enterprises & 1.5 & 0.8 & 11.3 \\
\hline & Other 336 industries & 67.0 & 50.2 & 956.3 \\
\hline & Total indirect impacts & 338.0 & 176.9 & 3,634 \\
\hline & \multicolumn{4}{|c|}{ Induced economic impact ${ }^{5}$} \\
\hline & Selected industry & $\begin{array}{c}\text { Induced output } \\
(\$ 000,000)\end{array}$ & $\begin{array}{c}\text { Value added } \\
(\$ 000,000)\end{array}$ & Employment (FTE) \\
\hline 30 & Power generation and supply & 13.1 & 8.9 & 29.0 \\
\hline 142 & Petroleum refineries & 13.2 & 0.5 & 2.7 \\
\hline 390 & Wholesale trade & 24.6 & 16.8 & 214.1 \\
\hline 401 & Motor vehicles and parts dealers & 14.4 & 9.1 & 144.2 \\
\hline 430 & Monetary authorities and depositories & 14.6 & 11.2 & 92.1 \\
\hline 431 & Real estate & 32.1 & 22.5 & 312.8 \\
\hline 465 & Offices of physicians, dentists, others & 26.9 & 19.1 & 320.5 \\
\hline 467 & Hospitals & 25.2 & 13.1 & 248.4 \\
\hline $464-466,478$ & All other medical, combined & 50.4 & 32.5 & 750.1 \\
\hline 481 & Food services and drinking places & 33.8 & 15.2 & 773.5 \\
\hline \multirow[t]{3}{*}{509} & Owner-occupied dwellings & 74.9 & 61.5 & 0.0 \\
\hline & Other 338 industries & 265.7 & 126.9 & $3,574.9$ \\
\hline & Total induced impacts & 589.1 & 337.2 & 6,462 \\
\hline
\end{tabular}

${ }^{1}$ NAICS $=$ North American Industry Classification System.

${ }^{2} \mathrm{FTE}=$ full-time equivalent.

${ }^{3}$ New Mexico Department of Labor Form 202, Albuquerque, NM, personal communication.

${ }^{4}$ USDA (2006); USDA (2007b).

${ }^{5}$ IMPLAN database and software. 
tries. As expected, many of these linked industries are related to the agricultural industry. However, many other nonagricultural economic activities (e.g., wholesale trade, real estate, petroleum refineries, oil and gas extraction, etc.) are also strongly related and affected by changes in the dairy farm industry. From the 373 industries available in the IMPLAN database for New Mexico, 352 of them showed some level of linkage with dairy farm activity.

\section{Induced Economic Impacts}

In terms of induced impacts, the dairy farm industry contributed $\$ 589$ million and 6,462 FTE to the New Mexico economy in 2005 (Table 2). These induced impacts had a value added to the New Mexico economy of $\$ 337$ million. Nonagricultural industries benefited largely from expenditures generated by the dairy farm industry. For example, the dairy farm industry induced output of food services and drinking places of approximately $\$ 34$ million. Likewise, dairy farm-related activities accounted for 248 FTE to hospitals (Table 2).

\section{Overall Economic Impacts of Dairy Farming to the New Mexico Economy}

The overall direct economic contribution of the dairy farm industry to the state's economy, in 2005 , was $\$ 1.03$ billion in sales to final demand (milk and meat processors), 4,221 FTE, and \$514 million in value-added activities (Table 2). This direct economic activity generated an indirect demand for good and services with a value of $\$ 338$ million and had an induced effect on households to the extent of $\$ 589$ million. As a whole, the dairy farm industry in New Mexico generated $\$ 1.98$ billion in total output and 14,313 FTE.

The New Mexico gross domestic product for 2005 was $\$ 69.7$ billion (US Department of Commerce, 2007). Agriculture was the fourth largest contributor to the state gross domestic product with a total value of $\$ 7.9$ billion, following the manufacturing, services, and mining industries. Dairy farming alone accounted for $13.1 \%$ of the agricultural output and for $1.5 \%$ of overall New Mexico economic output (Table 3). Of the 1.04 million FTE in New Mexico, the agricultural industry accounted for $6.7 \%$ of these jobs, and the dairy farm industry generated $20.5 \%$ of these agricultural jobs. Furthermore, our analysis revealed that indirect business taxes resulting from dairy farm-related activities totaled $\$ 25$ million, whereas the overall New Mexico state tax revenue from dairy farming (direct + indirect + induced activity) was $\$ 80$ million.

Not surprisingly, the impacts of dairy farming are particularly significant in those counties were the dairy

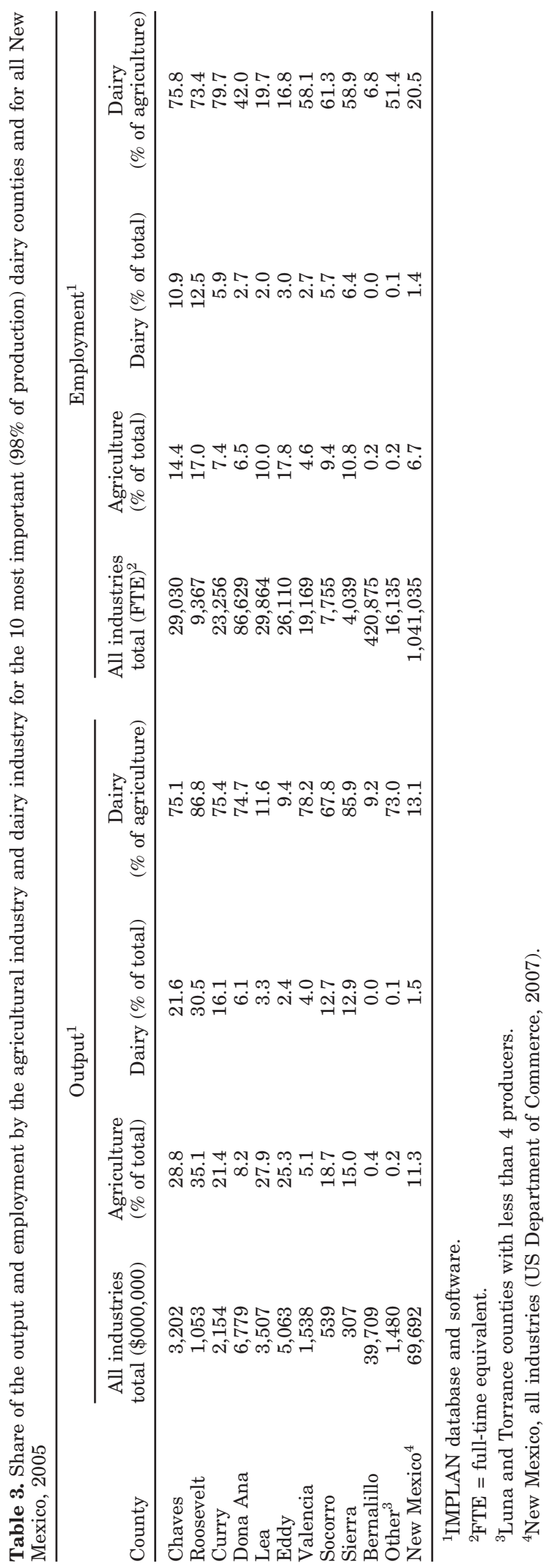


Table 4. Multiplier reports of the dairy industry in New Mexico

\begin{tabular}{|c|c|c|c|c|}
\hline Item & Direct & $\begin{array}{l}\text { Direct and indirect } \\
\text { type I multipliers }{ }^{1}\end{array}$ & Induced effects & $\begin{array}{c}\text { Total type } \\
\text { SAM multipliers }\end{array}$ \\
\hline Output & 1 & 1.34 & 0.58 & 1.92 \\
\hline Labor income $/ \$$ million & 48,591 & 125,662 & 74,162 & 248,415 \\
\hline Employment $\left(\mathrm{FTE}^{3}\right) / \$$ million & 4.10 & 7.63 & 6.28 & 13.91 \\
\hline
\end{tabular}

farms are located. Ten of the 33 counties in the state of New Mexico account for $98 \%$ of the state's dairy farming activity (Table 3). With the exception of Lea, Eddy, and Bernalillo counties (which are more economically diversified), dairy farming accounted for more than two-thirds the agricultural outputs and for more than two-fifths the agricultural employment in counties where dairy farms are concentrated.

\section{Multipliers of Dairy Farming in the New Mexico Economy}

Multipliers for dairy farming in New Mexico in 2005 are presented in Table 4 . For every $\$ 1$ million of dairy farm sales (final demand), there was $\$ 1.34$ million in direct + indirect impacts and $\$ 580$ thousand in induced impacts, resulting in $\$ 1.92$ million of total output in the state's economy. The output multiplier obtained for the New Mexico dairy farm industry was 1.98. Output multipliers reported in earlier studies on dairy farm economic impacts elsewhere in the United States include Ricketts (2000), who reported 2.60 for the industry in Missouri; Seidl and Weiler (2000), who reported 2.67 for the industry in northeast Colorado; and Doherty and Morse (1999), who reported 2.37 for the Minnesota dairy farm industry. Although the lower value of the output multiplier for New Mexico is generally consistent with the other states reported, it can be expected to increase over time as the industry grows and matures and becomes progressively more integrated into the regional economy.

Labor income as a ratio to value of output is also shown in Table 4. For every $\$ 1$ million of gross income, $\$ 49$ thousand was paid directly for labor on dairy farms, $\$ 126$ thousand was paid for labor in the allied industries, and $\$ 74$ thousand was paid for labor by the dairy farm service providers. As a result, $\$ 248$ thousand for every $\$ 1$ million in dairy farm outputs was paid as labor in New Mexico.

Table 4 also presents the impact of dairy farming on regional employment. For every $\$ 1$ million in dairy farm output, 4.10 FTE were created directly, 7.63 FTE were generated in dairy farming and allied industries, and
6.28 FTE were created in services provided to the dairy farm industry. Thus, for each $\$ 1$ million of sales of dairy farm products, 13.91 FTE were created in the New Mexico economy. The employment multiplier of 13.91 jobs/ $\$$ million found in this study for New Mexico is slightly lower than the 14.94 jobs $/ \$$ million multiplier reported for northeastern Colorado dairy farms (Seidl and Weiler, 2000).

\section{CONCLUSIONS}

In this study we quantified the economic role and identified the linkages between New Mexico's dairy farm industry and allied industries in terms of total economic impact, value added, and employment. New Mexico dairy farms generated a direct income of $\$ 1.03$ billion in 2005. The results showed that in 2005, New Mexico's dairy farm industry had a total economic impact of $\$ 1.98$ billion and accounted for 14,313 jobs. Therefore, New Mexico's dairy farming had an output multiplier (income) of 1.92 , a labor income multiplier of $\$ 248$ thousand/\$ million, and an employment multiplier of 13.91 jobs/\$ million.

The importance of New Mexico dairy farm linkages with almost all other industries in the state is underscored by its impact on employment. New Mexico dairy farms accounted for $13.1 \%$ of the agricultural output and $1.5 \%$ of the total economic output in New Mexico. Dairy farming also accounted for $20.5 \%$ of the agricultural jobs. Overall, dairy farming generated $\$ 80$ million in state tax revenues in 2005 in the state of New Mexico. This economic impact was even more significant in those counties where dairy farms are concentrated: Chaves, Roosevelt, Curry, Dona Ana, and Lea.

\section{REFERENCES}

Alvarez, A., J. del Corral, J. A. Pérez, and D. Solís. 2007. Efecto de la intensificación sobre la eficiencia de las explotaciones lecheras. Econ. Agrar. Recursos Nat. 7:91-106.

Aruna, P. B., F. W. Cubbage, K. J. Lee, and C. Redmond. 1997. Regional economic contribution of the forest-based industries in the South. Forest Prod. J. 47:35-45.

Balagtas, J. V., F. M. Hutchinson, J. M. Krochta, and D. A. Sumner. 2003. Anticipating market effects of new uses for whey and evalu- 
ating returns to research and development. J. Dairy Sci. 86:1662-1672.

Barham, B., J. Foltz, and U. Aldana. Expansion, modernization, and specialization in the Wisconsin dairy industry. Pages 42-48 in Status of Wisconsin Agriculture: 2005. Univ. Wisconsin, Madison.

Boggess, W. G., G. Johns, and C. Meline. 1997. Economic impacts of water quality programs in the Lake Okeechobee Watershed in Florida. J. Dairy Sci. 80:2682-2691.

Borden, G. W., R. R. Fletcher, and T. R. Harris. 1996. Economic, resource, and fiscal impacts of visitors on Washoe County, Nevada. J. Travel Res. 34:75-80.

Cabrera, V. E., and R. Hagevoort. 2007. Importance of the New Mexico dairy industry. Coop. Ext. Serv. Circ. 613. New Mexico State Univ., Las Cruces.

Doherty, B. A., and G. W. Morse. 1999. Economic importance of Minnesota's dairy industry. Ext. Serv. Bull. 07371. Univ. Minnesota, Minneapolis.

Helmberger, P., and Y. Chen. 1994. Economic effects of U.S. dairy programs. J. Agric. Resour. Econ. 19:225-238.

Hemmer, R. 1998. Some impacts of Arizona Department of Environmental Quality enforcement in the dairy industry in Maricopa County, Arizona. Pages 927-942 in Proc. Am. Agric. Econ. Assoc. Annu. Mtg., Salt Lake City, UT. Am. Agric. Econ. Assoc., Milwaukee, WI.

Leontief, W. 1953. Interregional theory. Pages 93-115 in Studies in the Structure of the American Economy. W. Leontief, ed. Oxford Univ. Press, New York, NY.

Miller, R. E., and P. D. Blair. 1985. Input-Output Analysis: Foundations and Extensions. Prentice-Hall, Englewood Cliffs, NJ.

Minnesota IMPLAN Group. 2006. IMPLAN data for New Mexico counties (2004). Minnesota IMPLAN Group Inc., Stillwater, MN.
Mon, P. A., and D. W. Holland. 2005. Organic apple production in Washington State: An input-output analysis. Renewable Agric. Food Syst. 21:134-141.

Ricketts, R. 2000. Economic impact of the Missouri dairy industry. A strategic plan for Missouri's dairy industry. Univ. Missouri, Columbia.

Rickman, D. S., and K. Schwer. 1995. A comparison of the multipliers of IMPLAN, REMI, and RIMS II: Benchmarking ready-made models for comparison. Ann. Reg. Sci. 29:363-374.

Robinson, M. H. 1997. Community input-output models for rural area analysis with an example from central Idaho. Ann. Reg. Sci. $31: 325-351$

Seidl, A., and S. Weiler. 2000. Estimated economic impact of Colorado dairies. Coop. Ext. Serv. APR 00-01. Colorado State Univ., Fort Collins.

Tavernier, E. M., and R. G. Brumfield. 2003. An economic analysis of the greenhouse, nursery, and sod sector in the United States. HortScience 38:128-130.

Templeton, S. R., and G. Goldman. 1996. Urban forestry adds $\$ 3.8$ billion on sales to California economy. Calif. Agric. 50:6-10.

USDA. 2006. New Mexico 2005 bulletin. Natl. Agric. Statistics Serv., Albuquerque, NM.

USDA. 2007a. Milk production, disposition and income, 2006 summary. Natl. Agric. Statistics Serv., Washington, DC.

USDA. 2007b. Statistical Summaries. Milk Market Administrator Southwest Federal Order 126. http://www.dallasma.com/index.jsp Accessed May 2007.

US Department of Commerce. 2007. Gross domestic product by state. Bureau of Economic Analysis. http://www.bea.gov/newsreleases/ regional/gdp_state/gsp_newsrelease.htm Accessed Jun. 28, 2007.

Waters, E., B. Weber, and D. W. Holland. 1999. The role of the agriculture in Oregon's economic base: Findings from a social accounting matrix. J. Agric. Resour. Econ. 24:266-280. 